\title{
Assessing the impact of alternative patent systems on the cost of health care: the TPPA and HIV treatment in Vietnam*
}

\author{
Hazel V J Moir, \\ Centre for European Studies, Australian National University \\ (hazel.moir@anu.edu.au) \\ Brigitte Tenni, \\ Nossal Institute for Global Health, University of Melbourne \\ Deborah Gleeson, \\ School of Public Health and Human Biosciences, La Trobe University \\ Ruth Lopert, \\ Department of Health Policy, George Washington University
}

\section{Asia-Pacific Innovation Conference, University of Technology Sydney}

27-29 November 2014

Contributed papers session: Suitability of IP Rights

(C)All commercial rights reserved. This is an early draft of our work, so please consult authors before quoting. Nothing in this work should be taken to reflect the views of any institution.

* We would like to thank Nguyễn Thanh Hương, from the Center for Supporting Community Development Initiatives (SCDI) in Hanoi for invaluable help in accessing data on Vietnamese patents and on medicine prices in Vietnam. 


\section{In memory of Emma Beruter}

This conference paper is dedicated to our co-researcher Emma Beruter, a health economist and PhD student who cared deeply about access to medicines in developing countries. The research reported here stemmed from her desire to use her skills to draw attention to the negative effects the TPPA could have on access to medicines in the developing world.

Sadly, Emma passed away unexpectedly in the early stages of our work together. We are indebted to her for her initiative, and for the work she put into the literature search and assessing models for later stages of the research. We are saddened by her loss but determined to continue the work she initiated. 


\title{
Assessing the impact of alternative patent systems on the cost of health care: Vietnam, the TPPA and HIV treatment in Vietnam
}

\begin{abstract}
In the Trans Pacific partnership Agreement (TPPA) negotiations, the United States has proposed expanded patent protections that will likely impact the affordability of medicines in TPPA partners. This includes antiretroviral (ARV) medicines used in the treatment of HIV/AIDS. Vietnam has the lowest GDP per capita (US\$1,911 in 2013) of the 12 countries participating in the TPPA negotiations. Official estimates suggest that in 2014 Vietnam had around 256,000 people living with HIV. ${ }^{1}$ By the end of 2013 antiretroviral (ARV) therapy was provided to 82,687 people $-68 \%$ of those meeting the clinical criteria for such medicines. ${ }^{2}$

Using the current Vietnamese patent regime as our base case, we analyse the potential impact of alternative patent regimes on access to ARVs in Vietnam. The two other scenarios investigated are a patent regime making full use of TRIPS flexibilities, and a regime based on the US proposals in the 2014 leaked draft of the TPPA intellectual property chapter.

Using World Health Organization (WHO) treatment guidelines, we identified the most commonly used chemical entities and combinations used in the treatment of HIV. We examined patent data sets to discover patents that had been registered for these medicines and used information from examination of these patents to identify which might be granted under alternative patent regimes. We then drew on the empirical literature to estimate prices under the three patent scenarios.

The current ARV budget was used as a constraint, with the consequence that the results focus on the impact of alternative patent regimes on access to treatment. Our results indicate $82 \%$ of the HIV population eligible for treatment would receive ARVs under a full TRIPS flexibility scenario, while only $30 \%$ of Vietnam's eligible HIV patients would have access to ARVs under the US 2014 TPPA proposals - more than halving the proportion treated compared to the current $68 \%$. Similar price impacts can be expected for other countries participating in the TPPA, though these are less economically vulnerable than Vietnam.
\end{abstract}

\section{Introduction}

The 1994 Agreement on Trade Related Aspects of Intellectual Property Rights (TRIPS) put an end to the option of excluding pharmaceutical patents from the patent system for countries that wished to participate in the World Trade Organization (WTO). It also required any WTO member to put in place other limitations on pharmaceutical competition, such as providing protection for 'test' data used to demonstrate safety and efficacy for regulatory approval. Concerns have been raised that various "behind the border" provisions in more recent trade agreements may reduce access to medicines, particularly in developing countries (Bhardwaj and Oh 2014; Chan 2014; Lopert and Gleeson 2013; Médecines Sans Frontières 2013). Of particular concern are the

\footnotetext{
1 AIDS Response Progress report for Vietnam, p.5. New cases were reported as around 14,000 a year (http://www.unaids.org/sites/default/files/country/documents//VNM narrative report 2014.pdf)

${ }^{2}$ AIDS Response Progress report for Vietnam, pp.22-23.
} 
TRIPS+ patent, data protection and data linkage provisions. These both lower the bar to the grant of patents - thus encouraging evergreening and delaying generic entry - and provide directly for longer periods of market exclusivity. Some agreements also limit the use of compulsory licensing to achieve access to lower priced medicines, despite the affirmation provided by the Doha Declaration.

Of particular note are the 2001 US-Jordan Free Trade Agreement, the earliest of these TRIPS+ agreements and the Australia-US Free Trade Agreement (AUSFTA), the first where a high income country agreed to lock in a range of TRIPS+ patent provisions that preference originator pharmaceutical manufacturers. ${ }^{3}$ Of even more concern is the proposed TPPA. Drafts of the intellectual property chapter of this agreement were leaked in 2011, again in 2013 and again in October 2014. ${ }^{4}$ While it is clear from the negotiating texts that many of the participating countries are resisting many of the US proposals, at present it is uncertain what will be finally agreed and with what trade-offs. Establishing this is made more complex by the fact that, in respect of market access provisions, the TPPA is really a set of bilateral agreements, rather than a plurilateral agreement.

Vietnam, with a GDP per capita of only US\$1,911 in 2013, ${ }^{5}$ and the lowest income country among the current TPPA partners, is arguably at greatest risk with respect to provisions that constrain access to affordable medicines. Such constrained access is of particular concern to people living with HIV. Vietnam's HIV population has grown rapidly and in 2011 was estimated at 248,500 (Duong et al. 2014). In 2013 approximately 121,600 people met the clinical criteria for ARV treatment, and $68 \%(82,687)$ were receiving such treatment. ${ }^{6}$ However there has been little empirical work to date on the possible effect of proposed TPPA provisions on ARV prices and access. This paper aims to fill that gap, and add to the empirical literature on the impact of patent policy on the prices of, and access to medicines.

Section 2 looks at the elements of TRIPS+ policy that can significantly affect medicine prices and therefore access to medicines. The limited empirical literature on the impact of patent policy on price and access to medicines in presented in Section 3. This provides a context for our study, and identifies likely patent-specific price variations. Section 4 reviews the HIV situation in Vietnam, the medicines used and their patent status. This section also reviews the pharmaceutical industry in Vietnam. Section 5 presents our data and models under our three scenarios. The results and their implications are presented in Section 6.

\section{TRIPS+ elements of the 2014 TPPA text}

Akaleephan and colleagues list ten elements of TRIPS+ policies that impact on medicines and pharmaceutical products (Akaleephana et al. 2009: 174-5):

(i) extended protection for test data;

\footnotetext{
${ }^{3}$ The AUSFTA is also noteworthy because in addition it represented the first attempt by the US to circumscribe a trading partner's domestic policy mechanisms intended to promote access to cost effective medicines for its residents.

4 See Flynn et al. 2012 for a discussion of the 2011 version. The 2013 leaked IP text is available at https://wikileaks.org/tpp/and the May 2014 version is at https://www.wikileaks.org/tpp-ip2/\#article_e4.

${ }^{5}$ World Bank GDP in current US \$s at http://data.worldbank.org/indicator/NY.GDP.PCAP.CD

${ }^{6}$ AIDS Response Progress report for Vietnam: 23-24.
} 
(ii) linkage between generic registration and originator patent status;

(iii) patent term compensation for delays in patent grant;

(iv) patent term compensation for delays in marketing approval;

(v) strengthening intellectual property law enforcement;

(vi) compulsory licensing restrictions, to national emergency non-commercial use;

(vii) parallel import limitations;

(viii) prohibition of patent revocation on public interest grounds;

(ix) patentability of new uses of products; and

(x) patentability of animals and plants (natural sources of medicines)."

While the leaked text shows substantial disagreement between negotiating parties as to the content of this chapter, there is a history of smaller technology-importing nations trading away control over patent policy in exchange for access to US markets, particularly for agricultural products. Because of this, our discussion of the TPPA proposals focuses on the content proposed by the USA. The US proposals go substantially further than previous trade agreements in tilting the patent system even more in favour of the business model of originator pharmaceutical companies. If accepted they would require legislative change in both the US and other partner countries. In addition to the TRIPS+ provisions identified by Akaleephan, the draft TPPA text further widens the scope of what can be patented and requires that the quantum of inventiveness for patent grant be set at a negligible level. The key elements proposed by the US in the 2014 draft are:

- $\quad$ Scope of patentability: Parties would be required to make patents available for any new uses or methods of using a known product (even where there is no improvement in efficacy). ${ }^{7}$

- Inventiveness requirement: The current very low test for inventiveness (not obvious to an unimaginative person of ordinary skill working in a narrowly defined area of technology) would be mandated (in a footnote to Article QQ.E.1).

- $\quad$ Presumption of validity: The US text calls for the presumption of validity for all granted patents. This would increase the hurdle required to prove a patent invalid.

- Revocation of patents: Removes ability to revoke a patent if there has been anticompetitive conduct.

- $\quad$ Patent term extension: Parties would be required to grant extensions to patent terms of up to 5 years to compensate for delays in the marketing approval processes and in granting patents. In the $2013 \mathrm{draft}$, term extensions for marketing approval delays were to be required not only for patents disclosing new pharmaceutical products, but also for method and use patents. The scope was narrowed in the 2014 draft to exclude term extensions for method and use patents.

- Data protection: Parties would be required to provide data protection for "undisclosed test or other data concerning the safety or efficacy of the product" for five years for new pharmaceutical products and three years for new uses or new indications of existing

\footnotetext{
${ }^{7}$ It is unclear from the text whether the USA is still pushing to remove diagnostic, therapeutic and surgical methods from allowed exclusions to patentability.
} 
products. ${ }^{8}$ In addition, the 2014 text includes a provision specifically related to biologic products, with the USA likely pursue eight to twelve years' protection.

- Patent linkage: Parties would be required to provide measures to prevent generic manufacturers from marketing a product during the term of a patent, and to provide for patent holders to be notified of generic product marketing applications. ${ }^{9}$

Overall the draft IP chapter is highly regulatory in its approach. Such detailed regulation has been substantially criticised for the costs it imposes on business, and a more modern approach is to regulate for desired outcomes leaving business free to innovate to achieve them. Here the detailed regulations mean that future democratically elected governments in signatory countries will be highly constrained in their ability to reform and improve the effectiveness of patent systems.

One of the most troublesome provisions is the requirement to determine patent eligibility, not on the basis of inventiveness, but on the basis of not being obvious. ${ }^{10}$ This is like short listing for a beauty competition by removing only the ugly. Most people fall between the ugly and the beautiful marks, just as most patent applications fall between the not obvious and inventive marks (Moir 2013). This is the most important doctrine giving rise to very low quality patents and hence to the problem of evergreening.

In November 2013 the US Trade Representative (USTR) announced a "differential approach" for developed and developing countries, ${ }^{11}$ particularly by providing developing countries with greater flexibility on phasing in data protection, patent term extension and patent linkage provisions. ${ }^{12}$ This approach drew heavy criticism from non-government organisations and academics as it still required lower income countries to accept inappropriate IP provisions in the longer term (Baker 2013; Médecines Sans Frontières 2013). As at October 2014, there is still significant disagreement remaining over the proposed new IP arrangements and the basis for determining when developing countries would adopt any new standards. ${ }^{13}$ It seems that whatever lower standard or transition mechanism is eventually negotiated, Vietnam will eventually be required to adopt whatever countries agree to as the new IP standard.

\footnotetext{
${ }^{8}$ This is a narrower provision that the 2013 text, where data protection was to be provided for all data used to support marketing approval.

9 The 2013 text would have required Parties to actively scan for existing patents covering an approved pharmaceutical product or its approved method of use, and delay granting marketing approval until any dispute over alleged infringement was settled.

${ }^{10}$ Footnote 54 to Article QQ.E.1 (2014 version), " In determinations regarding inventive step (or non-obviousness), each Party shall consider whether the claimed invention would have been obvious to a person skilled or having ordinary skill in the art having regard to the prior art."

${ }^{11}$ USTR (2013) Stakeholder input sharpens, focuses U.S. work on pharmaceutical intellectual property rights in the Trans-Pacific Partnership (Media Release). Retrieved 4 August 2014, from: http://www.ustr.gov/about-us/pressoffice/blog/2013/November/stakeholder-input-sharpens-focuses-us-work-on-pharmaceutical-IP-in-TPP.

12 Inside U.S. Trade (2013). In TPP, U.S. Floats 12-Year Data Period for Biologics, Flexibilities for Developing Countries. Posted: November 27, 2013.

${ }^{13}$ Inside U.S .Trade (2014) Leaked TPP Paper on drug IP landing zones shows extent of divisions. 1 August, 2014, and see continuing bracketed text in the 2014 version of the negotiating draft.
} 


\section{Empirical literature on patents, medicine prices and access to medicines}

In this part of the paper, we examine empirical studies that estimate the impact of patentrelated policies on the cost of and access to medicines. These studies fall into several categories. At the most macro level, there are three studies estimating the welfare impact of patent provisions for a whole economy. Other studies are more specific in their focus. A number of studies document the impact of generic entry on pharmaceutical prices. A further set investigate the extent of evergreening - the introduction of a range of patented small improvements which have the effect of delaying generic entry to the market. These include the increasing practice of originator companies marketing own-brand "generics" - discounted versions of their own products, often introduced just prior competitive generic entry. A fourth set of studies investigates the impact of particular forms of patent policy on medicine prices. These include studies of compulsory licensing, term extensions and patent linkage. A small proportion of these studies focus on medicines for the treatment of HIV/AIDS.

\subsection{Studies estimating the economy-wide welfare impact of patents}

Branstetter et al (2011) estimated the consumer surplus generated in the US by the paragraph IV provisions of the Hatch-Waxman Act ${ }^{14}$ (which facilitated generic entry to the market). Using a nested logit model they find that, over the period 1987 to 2008, consumer gains were around US\$92 billion with losses to producers of some US\$14 billion. With this net gain of some US\$78 billion, it is clear that the net gains from increasing competition in the pharmaceutical market are substantial.

Chaudhuri et al (2006) and Dutta (2011) both investigate the impact of introducing chemical product patents in the Indian market. Chaudhuri and colleagues use data on quinolones to estimate demand functions and supply elasticities in order to investigate five scenarios that might follow the introduction of pharmaceutical product patents. As with the Branstetter study, they find that consumer welfare losses substantially exceed producer gains. The total welfare loss to India from product patents on quinolone antibiotics alone is estimated at US\$144 to 450 million annually, while gains to the subsidiaries of foreign firms are just US\$19.6 to 53 million. With net welfare losses ranging from US\$124 to 397 million annually, it is clear that product patents are an expensive proposition for any society. The large disparity between gains to producers and losses to consumers is striking.

Dutta develops a model of demand, supply and entry for a cross-section of medicines in the Indian pharmaceutical market and uses this to derive counterfactual predictions of the implementation of TRIPS in India (Dutta 2011). For the 43 medicines covered, the average price increase is 42 per cent, and the consumer welfare loss US\$378m (an average loss of $\$ 9$ million per medicine). Dutta also estimates that patients covered fall by half, indicating a substantial impact on access. Again the benefit to patent rights holders is just $\$ 1.4$ million per medicine compared to the cost of new medicine development of some $\$ 300$ to 800 million (Dutta 2011: 177).

These three studies largely replicate the well-known facts from many studies of tariff barriers, demonstrating that they apply equally to the trade distortion arising from patent monopolies.

\footnotetext{
${ }^{14}$ The Drug Price Competition and Patent Term Restoration Act (Public Law 98-417), 1984.
} 
Where a domestic industry is protected by high tariff barriers, losses to consumers far exceed the gains to producers. It is therefore much more efficient to subsidise firms than to create or maintain tariff barriers. The impact of patents is similar. In effect patents operate as a form of tariff barrier leading to reduced competition and therefore high prices and high consumer welfare losses. Gains to producers are only 12 to 15 per cent of the loss to consumers. As with tariff barriers, it would be far more efficient to subsidise pharmaceutical product production than to grant product patents. It is ironic, therefore, that patent monopolies are required as part of the WTO's "free trade" suite of agreements.

It might be argued that over the longer term, there would be dynamic growth benefits to offset the immediate losses caused by pharmaceutical product patents. The experience of Italy refutes this. Prior to the introduction of pharmaceutical product patents in the 1970s, Italy was the world's major supplier of generic medicines. This thriving industry was decimated by product patents, and has not been replaced by an originator industry (Scherer and Weisburst 1995).

\subsection{Generic competition, prices and price elasticities}

Surprisingly, there are substantial differences between countries in the generics share of the pharmaceutical market, despite the fact that generics are bioequivalent and substantially cheaper. Dunne and colleagues (Dunne et al. 2013) summarise studies of the extent of generic prescribing, reporting the UK, with generics at 83 per cent $(2009-10)^{15}$ as being the maximum likely share of generics. The generic share in the USA has changed substantially over time - from just 14 percent in 1984, to 66 per cent in 2006 and 78 per cent by 2011. Ireland, with a very low generic share, is at the other end of the spectrum. Dunne and colleagues discuss barriers to the take-up of generic prescribing and conclude that substantial education of doctors is required. Italy too is a low generic share country and studies demonstrating equivalent therapeutic outcomes still seem necessary (Colombo et al. 2013). In fact this study of six therapeutic indications in five local health areas in Lombardy, finds superior compliance and persistence for generic products. Vietnam also has a very low generic share of prescribing (see section 5.5)

Accumulated research demonstrates that generic pharmaceutical prices are usually substantially lower than proprietary prices. In the USA, the Hatch-Waxman Act of 1984 clarified that generic companies have the right to enter markets immediately on patent expiry. Generic manufacturers can seek marketing approval by demonstrating bioequivalence to the originator. In effect they rely on originator clinical trial data to gain marketing approval rather than repeating costly clinical. ${ }^{16}$ Since it is unethical to carry out unnecessary trials on humans, there should never be any requirement for generic companies to replicate trials. ${ }^{17}$ Nonetheless, in

\footnotetext{
${ }^{15}$ Gatyas G: IMS Institute Reports U.S. Spending on Medicines Grew 2.3 Percent in 2010, to \$307.4 Billion. In: IMS Institute for Healthcare Informatics. IMS Website; 2011.

${ }^{16}$ Thus over-riding the Roche Products v. Bolar Pharmaceutical, 733 F.2d 858 (Fed. Cir. 1984) decision. Once a patent has expired, other firms have the right to sell into the market from the day after the patent ceases. The Bolar interpretation effectively extended the patent term. The Hatch-Waxman provisions reverse this, and are often referred to as Bolar provisions.

${ }^{17}$ World Medical Association, Declaration of Helsinki: Ethical Principles for Medical Research Involving Human Subjects, $18^{\text {th }} \quad$ World Medical Association General Assembly, Art. 20, http://www.wma.net/en/30publications/10policies/b3/17c.pdf. Given that Article 20 prevents the continuation of trials when conclusive results are known, one can presume that it is also unethical to commence such trials when there are already conclusive results.
} 
exchange for confirming that generic companies could rely on the original clinical trials to demonstrate safety and efficacy, originator companies were granted a 5-year period of data protection. During this period generic companies may not rely on the original clinical trial data to obtain marketing approval.

In a study funded by the major association of proprietary pharmaceutical companies in the USA (PhRMA, the Pharmaceutical Research and Manufacturers of America), Berndt and Aitken (2011) find that in the period 1984 to 2009 there has been not only a big increase in the generic share of the market, but that the proportionate price fall after generic entry has increased. In 1994 the price fall in the 24 months after generic entry for nine therapeutic classes was 35 per cent; in 2009 it was 72 per cent. Using data on prices paid by US retail pharmacies, Frank and Salkever (1997) study 32 medicines which first experienced generic competition in the mid 1980s. They find, as anticipated, that the average price paid for a medicine falls after generic entry. The decrease is larger, the greater the degree of competition between generic products. But they also find a tendency for there to be small price rises for the originator product. These findings suggest that the pharmaceutical market can be quite segmented. ${ }^{18}$

In a study of 35 active pharmaceutical substances in ten European countries, Dylst and Simoens found that the magnitude of the fall in price with generic entry differs according to the overall generic market share. For the period June 2002 to March 2007 market volume rose by similar amounts in both low and high generic share markets ( $+29 \%$ and $+27 \%$, respectively), while price falls were $-43 \%$ for high generic share countries and $-22 \%$ for low generic share countries (Dylst and Simoens 2011).

In Germany, Stargardt (2011) finds that competition trumps regulation when it comes to achieving affordable prices for medicines. Using a four-level random intercept model and pharmacy-level price and volume data for January 2004 to June 2006, he found that reference pricing and temporary price freezes were effective in moderating medicine prices. For offpatent medicines the degree of competition had an even greater impact. Competition was shown to be important not only within but also between therapeutic classes.

\subsection{Evergreening: using the patent system to obtain low quality patents}

Clearly, if generic entry is delayed prices will remain high and access will consequently be more limited. There are several different means of achieving delayed generic entry. Pharmaceutical companies have persuaded some governments to adopt TRIPS+ provisions that provide formal term extensions, data exclusivity privileges, or patent linkage. In addition pharmaceutical companies have exploited low patent standards to obtain additional patents on minor variations to existing pharmaceuticals.

Thus known chemical variants such as metabolites, esters, salts and isomers are regularly

\footnotetext{
${ }^{18}$ With segmented markets, demand elasticities vary significantly between income groups. At the upper income levels demand for pharmaceutical products may not change much with price (be highly price inelastic), while at lower income levels demand falls rapidly as price increases (there is high price elasticity). In such markets there is a strong incentive for a company with a product monopoly to price for the highest income segment and leave the remainder of the population unserved (Flynn, Hollis and Palmedo 2009). Examples of this phenomenon include the higher prices charged for amlodipine, ciprofloxacin and sertraline in Brazil and Mexico than Sweden or the UK - in these lower income countries, companies are only supplying those who will pay a high price (Maskus 2001).
} 
granted patents, even though the original compound has already benefited from a patent monopoly. Companies have also been able to persuade governments to grant additional patents for specific new uses or forms of things that have already been patented, even though the original patent already provided exclusive commercial use of the compound in any way or form. Further, combining known compounds with known methods of delivery has been deemed sufficient to achieve yet more patents. These additional, secondary, patents can substantially extend patent life. ${ }^{19}$ Evergreening patents are the sub-set of secondary patents owned by the company producing the new active pharmaceutical ingredient (API).

Amin and Kesselheim (2012) identified the evergreening patents associated with two important HIV medicines, ritonavir and lopinavir. The original ritonavir patent was filed in the USA in 1995, granted in 1996 and expires on 25 April 2015. The original lopinavir patent was filed in 1996, granted in 1999, and expires on 21 November 2016. As at April 2011 a further 108 patent items were found for these two medicines -82 granted patents and 26 applications. Together these evergreening patents could delay generic entry to at least 2028 - some 13 to 14 years after original patent expiry. These evergreening patents cover related chemical structures, methods of manufacture and methods of treatment.

In a more general study of evergreening in the USA, Kapczynski and colleagues (2012) found that secondary claims were common and added, on average, 6.5 years to patent life. Patents filed late during the life of the original compound were more common for higher sales medicines. Ouellette, also using US data, finds the average number of patents per medicine increased over time, from 2.5 in the late 1980s to nearly 3.5 in 2005, a statistically significant increase (Ouellette 2010: 316). While there is considerable variation between therapeutic groups in the mean number of patents per medicine, the mean was highest for "block-buster" medicines - over 5 patents/medicine in the 2002-04 period.

In Canada, Bouchard et al. (2010) found a mean of 40 patents per medicine. In Australia too the average number of evergreening patents is higher than in the USA. On average, there are 49 patents per API, of which about 25 per cent are held by the originator company - about 12 evergreening patents per API (Christie et al. 2013: 4). For Europe too evergreening patenting is prevalent for pharmaceuticals and again the average number of patents per API was greater for the highest volume medicines (European Commission 2009: 10-11). For top-selling medicines the average number of patents and patent applications was 237, compared to 98 for medicines in general.

The strategy of taking out many secondary patents is referred to within the industry as "lifecycle management". Some of the literature on lifecycle management simply discusses strategies, including what kinds of secondary patents will survive legal challenges in which countries. ${ }^{20}$ This literature notes the value to originator pharmaceutical companies of patent litigation even on very weak (uninventive) patents as the returns achieved from an additional period without generic competition while the matter is before the courts will "easily outweigh the costs of

19 See Alphapharm submission to the 2012-2013 Australian Pharmaceutical Patent Review (http://www.ipaustralia.gov.au/about-us/ip-legislation-changes/review-pharmaceutical-patents/ accessed 23 August 2014). Submissions to the review have been removed from the website, but a copy can be obtained from the authors.

${ }^{20}$ See for example Burdon and Sloper 2003; Furrow 2008; Kvesic 2008. 
patent litigation" (Burdon and Sloper 2003: 238). If such secondary patents delay the entry of generics beyond the term agreed in the patent bargain, this is a matter of substantial public policy concern.

Increasingly originator pharmaceutical companies also own generic producers (Hollis 2003). Kong and Seldon (2004) investigate the possible role of links between originator and generic companies in deterring generic market entry. Licensed generics - also known as pseudogenerics - comprise a significant share of the market in Australia and are also present in the German, Swedish, UK and New Zealand markets. Kong and Seldon find that pseudo-generics are used more to gain a share of the generics market than to block generic entry.

A more recent aspect of evergreening has been the marketing of a 'generic" by the original owning company, combined with a strategy positioning the original medicine at a higher price point once genuine generics enter the market. In a game-theoretic analysis Kamien and Zang suggest that if the originator's (pseudo) generic product is introduced before general entry of generics, both consumers and originator companies benefit (Kamien and Zang 1999). There is evidence that overall use of a given medicine in the USA declines prior to generic market entry (Huckfeldt and Knittel 2011). This decline coincides with increased use of originator reformulations of the soon-to-be-out-of patent medicine and case study evidence indicates that advertising plays a key role in these changing usage patterns. The typical reformulation is an extended-release version of the original product. There are few studies comparing clinical outcomes of extended release compared to original formulations, and drug approval authorities do not require proof that extended release versions provide superior outcomes in order to grant market approval. Huckfeldt and Knittel conclude that "rather than society enjoying the consumer surplus from competitive pricing after generic entry, utilization is shifted towards other still-patented drugs." (Huckfeldt and Knittel 2011: 19).

\subsection{The impact of patent policy, including trade agreements, on medicine prices}

Prior to TRIPS many countries did not allow pharmaceuticals to be granted for chemical compounds, emulating the highly successful strategy that had led to the German chemical industry to become globally dominant (Dutfield 2003). Germany granted patents only for chemical processes, so companies sought ever more productive means of manufacturing. Following the signing of the European Patent Convention (EPC) in the early 1970s, European countries were obliged to provide patents for chemicals. Italy lost its role as the leading global supplier of generic medicines (Scherer and Weisburst 1995), being replaced by India. As noted in Section 3.1, there is a substantial national welfare loss associated with patenting pharmaceutical compounds, greater in magnitude than the benefit to pharmaceutical producers by a factor of 6.5 to 8.5 .

Lower income countries were allowed to phase TRIPS in over time, though many were persuaded to implement TRIPS immediately in exchange for promised higher foreign direct investment (FDI) (Deere 2009). The first of the TRIPS+ trade treaties was the 2001 agreement between the USA and Jordan. Since then the US has signed a number of bilateral treaties incorporating TRIPS+ provisions that favour longer and stronger market exclusivity for pharmaceutical products. Some of these are too recent for any evaluation of their impact to be possible, but there are several studies of outcomes in countries with older treaties. There are 
also several studies that model the predicted impact of provisions proposed for different trade agreements.

Before 2000 Jordan relied heavily on generic medicines. TRIPS was adopted in 2000 and TRIPS+ rules in 2001. The TRIPS+ rules are: patent term extensions to offset marketing approval delays, limits to parallel importing and compulsory licensing, five years of data protection plus three years for new uses of known compounds and patent linkage notification (Oxfam International 2007: 7). The Oxfam study finds that since 2001 medicine prices in Jordan have increased by 20 per cent, and data protection has delayed generic entry for 79 per cent of medicines newly launched between 2002 and 2006. Egypt has also implemented TRIPS but does not have TRIPS+ policies. In comparison to Egypt, medicine prices are between two and six times higher in Jordan (Oxfam International 2007: 10). Adjusting for sales volume and inflation, Abbott and colleagues find that between 1999 and 2004 there was a 17 per cent increase in total medicines expenditure in Jordan (Abbott et al. 2012). Compared to the Oxfam study, Abbott and colleagues find a loss of \$US18 million in 2004 - larger than the additional outlays of between US\$6 and 22 million between 2002 and 2006 found in the Oxfam study. This is largely due to more comprehensive medicine data in the Abbott study. Abbott and colleagues conclude that the provision for data protection has the most significant effect on the price of medicines.

Thailand does not have a TRIPS+ trade agreement, though there were active discussions with the USA in the period 2004-06. There was substantial civil unrest over proposed policies that would have significantly increased the price of HIV medicines and trade negotiations were abandoned. ${ }^{21}$ The proposed TRIPS+ elements have been extensively analysed. Thailand introduced TRIPS provisions in 1992 - eight years ahead of the required date of 2000. This early introduction was as a result of trade pressure from the USA (Akaleephana et al. 2009).

Using 2000-03 data on domestic production and import volumes for 74 medicines (accounting for about half the pharmaceutical market in Thailand), and taking hospital wholesale prices as the base, Akaleephana and colleagues find that extending market exclusivity for 5 years (i.e. delaying generic entry) would increase 2002 medicine outlays by between 9 and 45 per cent (Akaleephana et al. 2009). Kessomboon and colleagues (2010) have also estimated the cost if Thailand had extended patent terms and provided market exclusivity for test data. For 2027 they estimate such provisions would have increased the medicine price index by 32 per cent and outlays by US\$11 million. Losses to domestic pharmaceutical companies would be US\$3 million.

The Central America Free Trade Agreement (CAFTA) includes term extensions to compensate for unreasonable delays in granting patents or obtaining marketing approval. It also requires five years of data protection for all new products, a wider scope than the usual limitation to new chemical entities. Patent linkage provisions shift responsibility for enforcement to the state (Godoy and Cerón 2011: 1187-88). Implementation differs between member countries, with different medicines covered in different countries. Shaffer and Brennan (2009) limit their assessment to the data protection provisions in Guatemala, a country with a domestic pharmaceutical industry. They found prices to be substantially higher for medicines with data protection and that this also delayed generic entry. With regard to HIV/AIDS medicines, five protease inhibitors (a key class of second-line ARVs) are listed for data protection in Guatemala.

\footnotetext{
${ }^{21}$ See http://www.ustr.gov/countries-regions/southeast-asia-pacific/thailand
} 
For example, Abbott's lopinavir/ritonavir (Kaletra) was registered for data protection in November 2005 although a generic version was already registered in August 2004. The open contract price for Kaletra was $\$ 472.09$ - a mark-up of 166 per cent compared to the PanAmerican Health Organization price of \$284.89 (Shaffer and Brenner 2009: w 964).

The Comprehensive Economic and Trade Agreement between the European Union (EU) and Canada (CETA) - a highly detailed document running to 1,634 pages - will lead to three changes in policies affecting pharmaceutical pricing in Canada but none in Europe. Canada will be committed to further patent term extension provisions; the current lengthy term of data protection will be locked in and there will be new appeal rights with regard to patent linkage provisions. The EU prohibits patent linkage provisions in member countries, yet has sought these in Canada. Lexchin and Jones estimate that these provisions will increase Canadian pharmaceutical outlays by 6.2 to 12.9 per cent from 2023 (Lexchin and Gagnon 2014). These estimates are based on a re-working of analysis by Grootendorts and Hollis, estimating the cost of the EU proposals, not all of which were finally implemented (Grootendorst and Hollis 2011a; 2011b). It should be noted that the Grootendorst and Hollis study was funded by the Canadian Generic Pharmaceutical Association (CGPA).

Colombia and Peru also have trade treaties with the EU. The IFARMA Foundation modelled the impact of the proposals on expenditure and access to medicines using WHO guidelines and the intellectual property rights impact assessment (IPRIA) model (IFARMA and Fundacion Mision Salud 2009a; 2009b). In fact the draft proposals (for eight to 11 years of test data exclusivity and 4 years term extension) were substantially modified. ${ }^{22}$ The proposed patent term extension was estimated to cost US\$329 million and lead to a 7 per cent decrease in consumption in Colombia and in Peru would cost US\$159m with a 9 per cent decrease in consumption. In Colombia the proposed data protection provisions were estimated to cost US\$437 million in 2025 (US\$300m in Peru) and lead to an eight per cent decrease in consumption. For Peru, the estimates were based on US data for 2005-08 to estimate the length of market protection with and without term extensions. As the final provisions were far less extensive, so too will be the costs.

Another issue in predicting the impact of trade policies on health provision is the direct impact on suppliers of generic medicines. At present Indian generic manufacturers dominate the ARV market, supplying more than 80 per cent of the market (Waning, Diedrichsen and Moon 2010). However new ARVs recommended by the WHO are earlier in their patent lives and are more expensive than current treatments by a factor of three or four. ${ }^{23}$ Further supply of generic versions of new ARVs may be impeded by the term of the underlying patents.

Another cause of delays in generic market entry is a practice called patent linkage. ${ }^{24}$ Canada adopted patent linkage in 1993 when it joined the North American Free Trade Agreement

\footnotetext{
22 The final agreement provides for, but does not mandate, term extensions for delays in marketing approval (Article 230); five years market exclusivity for pharmaceutical test data (Article 231 - new chemical entities only). http://trade.ec.europa.eu/doclib/docs/2011/march/tradoc 147704.pdf Title VII (accessed 28 August 2014).

${ }^{23}$ Waning and colleagues report that new tenofovir-based regimens, supplied by India, cost $\$ 246$ to $\$ 309$ per person per year, which is 3.3 to four times the price of older regimen medicines (3tc/NVP/d4T30). Médecins Sans Frontières (2014) also note the very high price of third-tier treatments including new versions of tenofovir, which have not yet completed clinical trials.

${ }^{24}$ Baker provides a detailed discussion of the background to data exclusivity and patent linkage in the USA, where both policies originated (Baker 2008).
} 
(NAFTA). The Patented Medicine Notice of Compliance (NOC) Linkage Regulations tie regulatory approval of generic medicines to the patent status of the originator product. There has been contention over whether the desired outcome of balancing public interest in early entry and innovator interests in maintaining exclusive markets has been achieved. Writing some 17 years after their introduction, Lexchin (2011) noted the dearth of empirical work on their impact. Bouchard et al. (2010) found that on average only 5 per cent of the mean of 40 patents per medicine were actually on the linkage register. Bouchard has also shown that the empirical effect of Canada's linkage regulations is to increase the average patent term by about 22 years, "representing a doubling of the duration of patent protection beyond that associated with the originating patent" (Bouchard et al. 2009: 1499).

\section{Compulsory licenses}

One means of ensuring affordable access to essential medicines is through the issue of a compulsory license $(\mathrm{CL})$ with respect to the patents preventing generic competition. Under a compulsory license the issuer pays a royalty for use of the patent, usually set to provide normal rather than high profit returns. Since the adoption of TRIPS, the ability of countries to issue compulsory licenses has been constrained, though the response of the USTR to issue of a CL is usually a stronger sanction. The way in which TRIPS was drafted meant that only countries with domestic manufacturing capability could benefit from CLs.

The Doha Declaration was meant to make it easier for countries without generic manufacturing capabilities to obtain essential medicines under compulsory licenses. But the resulting "paragraph 6 solution" is so complex that few generic manufacturers would be willing to use it (Drahos 2007). Although a number of developed countries have now introduced legislation to implement the paragraph 6 solution there are few examples of its use. One of these is the oneoff shipment of 7 million doses of ARVs from Canada to Rwanda in 2008 (Weber and Mills 2010).

So it largely remains the case that only countries with domestic manufacturing capabilities can make credible threats to produce medicines under compulsory license. One such country is Brazil. Prior to implementing TRIPS pharmaceutical products were unpatentable in Brazil, and a flourishing generics industry had developed. In the period 1996 to 2001 the cost of locally produced non-patented medicines dropped by 75 per cent and eight of 13 ARVs supplied by the Brazilian Ministry of health were locally produced (Rosenberg 2014:3).

Cohen and Lybecker analyse negotiations between Brazil and Roche over domestic production of the AIDS medicine nelfinavir. In 200028 per cent of ARV spending was on this single medicine. During protracted negotiations with Roche, the government was successful in negotiating major cuts to prices for other ARVs. Eventually nelfinavir was also obtained at a substantial discount (Cohen and Lybecker 2005). It is unclear what the final agreed price was but Cohen and Lybecker refer to discounts on Merck ARVs of between 59 and 64 per cent. In 2007 Brazil issued a CL for the ARV efavirenz (Veras 2014: 2).

Brazil has also adopted unique procedures for setting the height of the inventive step for pharmaceutical patents (Shadlen 2011). In 2009 the Brazilian National Institute of Intellectual Property (INPI) rejected the application for a patent for tenofovir disoproxil fumarate (TDF). Two years later Brazil started producing generic tenofovir (Veras 2014). 
Beall and Kuhn (2012) reported that since the Doha Declaration there had only been 24 cases of compulsory licensing involving WTO member countries. Thailand has been the most active user of CLs. Like Brazil and Vietnam, Thailand has domestic manufacturing capability. Through the late 1990s there were substantial negotiations between Thailand and the USA over the price of essential ARVs. By the early 2000s access to second-line ARVs efavirenz and lopinavir/ritonavir was critical. During the same period there were active negotiations between Thailand and the USA over a trade agreement, with the US proposing further restrictions on compulsory licensing. There was substantial civil action both over access to ARVs and over the proposed trade agreement (Rosenberg 2014: 6). In 2006 the military government issued compulsory licenses for both lopinavir/ritonavir and efavirenz, as well as for the anti-platelet agent, clopidogrel.

During the period from 1969 to 1987 Canada used compulsory licensing provisions to promote competition between originator medicines and generics, controlling the cost of medicines. However in 1987 Canada introduced a policy limiting the use of CLs, and in 1993 ceased using CLs as a means of controlling medicine prices. Using data from British Colombia for 1981 - 94, Jones and colleagues (2001) investigated the impact of originator-generic competition on medicine prices. For the sample of 82 therapeutic drug categories they found that generic competition moderated medicine prices but that this effect was reduced after 1987 . They also found that price falls after 1987 were slower and lower. Within the generics market, there is a strong effect of first entry, with the first generic gaining a substantial market share as well as prices above the minimum. The Patent Medicine Price Review Board operated throughout this period. The overall conclusion from the study is that facilitating generic entry, and therefore competition, reduces prices.

\section{$4 \quad$ Comparison scenarios}

We estimated the outcomes of three scenarios on the cost of ARVs in Vietnam. Scenario 1, the baseline, uses the current IP provisions in Vietnam's patent law. Scenario 2 was based on full implementation of the flexibilities permitted in the WTO's TRIPS Agreement and affirmed in the Doha Declaration. Scenario 3 was based on provisions included in US proposals for the TPPA. Details of the three scenarios are shown in Table 1.

In Scenario 1 patents are granted for inventive products and processes but not for new uses or methods of using known compounds. The patent term is 20 years from filing, and there are no term extensions. Data protection applies for undisclosed clinical trial data for new chemical entities and new combinations of known entities, but is not automatic. All new chemical entities and new combinations of known entities may gain 5 year data protection. ${ }^{25}$

\footnotetext{
25 This scenario is based on Vietnam's Law on Intellectual Property (No. 50/2005/QH11), the 2006 Regulation on Data Security of Drug Registration Records and the 2009 Law Amending and Supplementing a Number of Articles of the Law on Intellectual Property. We also drew on comparisons by Kiliç and Maybarduk (2011) of current Vietnamese law and the 2011 US TPP proposals in developing this scenario.
} 
Table $1 \quad$ Assumptions in different scenarios

\begin{tabular}{|c|c|c|}
\hline Scenario & Elements included in the model & Assumptions \\
\hline $\begin{array}{l}\text { 1. Current IP } \\
\text { provisions in } \\
\text { Vietnam }\end{array}$ & $\begin{array}{l}\text { Patents for products and } \\
\text { processes, but not new uses or } \\
\text { methods of using existing drugs. } \\
20 \text { year patent term; no patent } \\
\text { term extensions. } \\
\text { Protection for undisclosed data; } \\
\text { only applies to new chemical } \\
\text { entities and new combinations of } \\
\text { known entities. } \\
\text { No patent linkage. }\end{array}$ & $\begin{array}{l}\text { Data protection is not automatic, } \\
\text { and must be applied for. For the } \\
\text { purposes of the model, } 5 \text { years of } \\
\text { data protection for undisclosed data } \\
\text { is assumed and it is assumed this } \\
\text { will apply to all new chemical } \\
\text { entities and new combinations of } \\
\text { known entities. }\end{array}$ \\
\hline $\begin{array}{l}\text { 2. Full } \\
\text { implementation of } \\
\text { TRIPS flexibilities }\end{array}$ & $\begin{array}{l}\text { Compulsory licensing of all second } \\
\text { and subsequent line ARVs (i.e. all } \\
\text { ARVs that are not currently } \\
\text { available as generics). } \\
\text { Ability to set the inventive step to } \\
\text { exclude combinations of known } \\
\text { things unless they demonstrate } \\
\text { synergy. }{ }^{26} \\
\text { No patent term extensions. } \\
\text { No data protection. }\end{array}$ & $\begin{array}{l}\text { We assume that Vietnam would } \\
\text { adopt at least: } \\
\text { - the European synergy } \\
\text { standard for combinations; } \\
\text { - } \text { processes used in Brazil to } \\
\text { ensure a reasonable } \\
\text { inventiveness standard; and } \\
\text { - a requirement for at least } \\
\text { enhanced efficacy in } \\
\text { implementing the } \\
\text { inventiveness standards. }\end{array}$ \\
\hline $\begin{array}{l}\text { 3. Highest level of } \\
\text { IP protection } \\
\text { advocated for by } \\
\text { the US in the TPPA } \\
\text { negotiations }\end{array}$ & $\begin{array}{l}\text { Patents for new uses and methods } \\
\text { of using existing drugs. } \\
\text { 5-year patent term extensions for } \\
\text { new pharmaceutical products. } \\
\text { Five years of data protection for } \\
\text { new pharmaceutical products, } \\
\text { plus an additional } 3 \text { years for new } \\
\text { indications. }\end{array}$ & $\begin{array}{l}5 \text { years of PTE for the first patent } \\
\text { (making the conservative } \\
\text { assumption that it will only apply to } \\
\text { the patent disclosing the molecule). } \\
\text { Assume thereafter that PTE is not } \\
\text { applied. } \\
5 \text { years data protection for } \\
\text { undisclosed data plus additional } 3 \\
\text { years for new indications. }\end{array}$ \\
\hline
\end{tabular}

Scenario 2 is based on using the full TRIPS flexibilities. We have assumed that as part of this Vietnam adopts at least the European synergy standard for combinations, the processes used in Brazil to ensure a reasonable inventiveness standard for patents underlying pharmaceutical products and a requirement for at least enhanced efficacy in implementing the inventiveness standard. No term extensions are provided for patents and there are no data protection

\footnotetext{
${ }^{26}$ The synergy doctrine requires that a new combination of known things demonstrate either a surprising effect or an effect greater than the sum of the parts in order to pass the inventiveness requirement for a patent.
} 
privileges operating. Further, we assume that Vietnam, given its domestic generic industry, has issued compulsory licenses for all first and second-line ARVs that are not available as generics.

Scenario 3 is based on the IP proposals put forward by the USTR in the May 2014 version of the TPPA leaked IP chapter. Patents are provided for new uses and methods of using known compounds, and the "not obvious to an ordinarily skilled person" test is used such that almost every minute variation on known compounds, processes, formulations and uses are granted patents. Term extensions are provided for new chemical entities. All undisclosed clinical trial data required by regulatory agencies have 5 years' protection for new chemical entities and three years for new uses.

The basic data for the scenarios are developed in the next section, where we discuss Vietnam's HIV experience, the preferred treatment medicines and their patent status, and prices for these medicines in Vietnam and globally.

\section{Vietnam: HIV prevalence and the capacity of local industry to ARVs}

In this section we provide brief background information on HIV in Vietnam, before discussing the medicines used in treatment (section 5.2). We then explore the current patent status of the first-line medicines (section 5.3) in order to estimate what patents might be in place under alternative patent policy scenarios (section 5.4). We then discuss the availability of ARVs in Vietnam, including prices and comparisons with global prices (section 5.5).

\subsection{HIV prevalence in Vietnam}

Vietnam will have a total of 256,000 people living with HIV by the end of $2014 .{ }^{27}$ The majority (79 per cent) are in the prime working ages - between 20 and 39. HIV infection is largely concentrated in people who inject drugs, female sex workers and men who have sex with men. According to the 2013 HIV sentinel surveillance in 41 provinces, the average HIV prevalence for these groups ranges from $2.6 \%$ to $10.3 \%{ }^{28}$

HIV treatment is largely funded by foreign donors, the Global Fund to Fight AIDS, Tuberculosis and Malaria (GFATM) and the U.S. President's Emergency Plan for AIDS Relief (PEPFAR). The treatment is composed of a prevention package and a care and treatment package. In 2012, a total of US\$25.1 million was spent on HIV care and treatment, which accounted for $26.3 \%$ of total spending on HIV \& AIDS in Vietnam. In 2012, international aid funded $86 \%$ of Vietnam's HIV care and treatment, the remaining $14 \%$ coming from the Vietnamese national budget (Figure 1). ${ }^{29}$

\footnotetext{
${ }^{27}$ Government of Vietnam, Declaration of Commitment on HIV and AIDS (UNGASS) Report, 2012.

${ }^{28}$ National Committee for AIDS, Drugs, Prostitution Prevention and Control. Vietnam AIDS Response Progress Report. Following up the 2011 Political Declaration on HIV AIDS. Reporting Period January 2012- December 2013. Hanoi 2014.

${ }^{29}$ National Committee for AIDS, Drugs, Prostitution Prevention and Control. Vietnam AIDS Response Progress Report. Following up the 2011 Political Declaration on HIV AIDS. Reporting Period January 2012- December 2013. Hanoi 2014.
} 
Figure 1 Spending on prevention, treatment and care by financial source, 2012

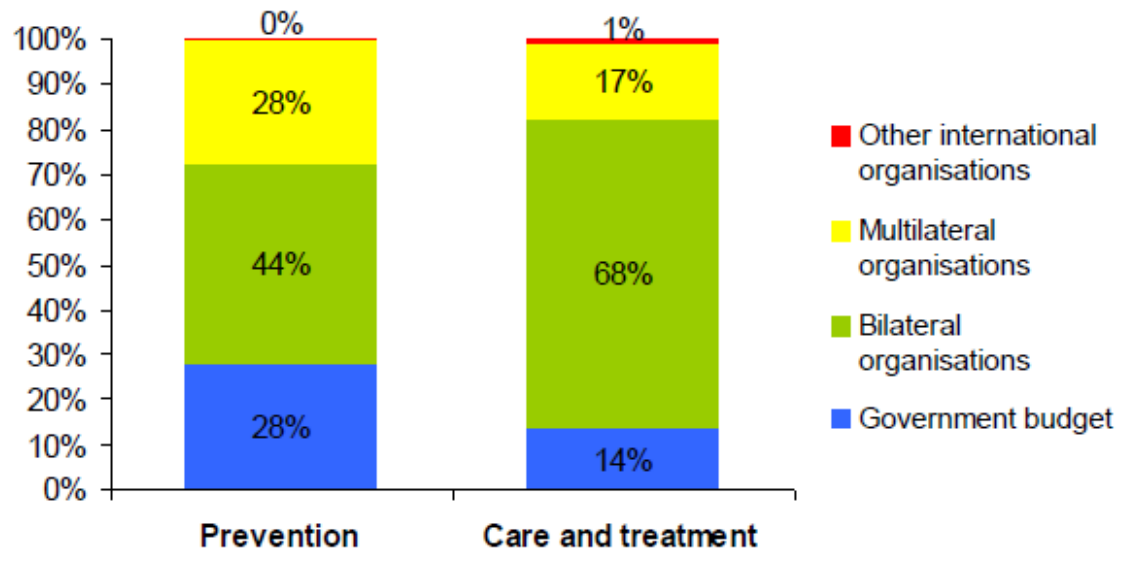

Source: $\quad$ See footnote 23.

Despite the fact that ARV medicines are supplied free of charge, the Futures Group estimated that total healthcare expenditure for people living with HIV households in Vietnam was 13 times higher than the average household spending in 2004. Such households are at greater risk of poverty. The study concluded that by $2015,504,000$ people will either become newly poor or fall deeper into poverty because of HIV. ${ }^{30}$ By the end of 2013, ARV treatment was provided free of charge from 364 HIV outpatient clinics of which 56 provided services in closed settings. ${ }^{31}$

\subsection{Medicines used to treat HIV in Vietnam}

Ministry of Health Guidelines for Diagnosis and Treatment of HIV/AIDS and National ART Protocol outline the criteria for starting antiviral treatment. ${ }^{32}$ Both first-line and second-line regimens include combinations of three or more medicines (see Table 2). ${ }^{33}$ The current preferred first line regimen is the combination of tenofovir, lamivudine, and efavirenz (or nevirapine).

\footnotetext{
${ }^{30}$ The Futures Group International, Impact of HIV/AIDS on Household Vulnerability and Poverty in Viet Nam, 2004 (hereafter, Futures Group, 2004).

31 VAAC, MoH. D28 Routine Program Report. 2013. Because many people living with HIV are sex workers or injecting drug users, they may be in closed facilities, such as detention centres.

${ }^{32}$ Ministry of Health. National Guidelines for Diagnosis and Treatment of HIV/AIDS. 2009.

${ }^{33}$ First-line treatments are treatments for a person first taking ARVs. If that person develops resistance to the firstline drugs, then second-line drugs are prescribed.
} 
Table 2 Vietnam Ministry of Health Revised HIV treatment guidelines, 2011

\begin{tabular}{|c|c|c|c|c|}
\hline \multicolumn{5}{|c|}{ First-line ARV regimens: } \\
\hline \multicolumn{5}{|l|}{ Prioritized regimen: } \\
\hline $\begin{array}{c}\text { tenofovir disoproxil } \\
\text { fumarate (TDF): } 300 \mathrm{mg} \\
\text { daily }\end{array}$ & + & $\begin{array}{l}\text { lamivudine } \\
(3 T C) \\
2 \times 150 \mathrm{mg} \\
\text { daily } \\
\end{array}$ & + & $\begin{array}{c}\text { nevirapine (NVP): } 2 \times 200 \mathrm{mg} \text { daily }{ }^{(\mathrm{a})} \\
\text { or } \\
\text { efavirenz (EFV): } 1 \times 600 \mathrm{mg} \text { at night }{ }^{(\mathrm{b})}\end{array}$ \\
\hline \multicolumn{5}{|l|}{ Alternative regimen } \\
\hline $\begin{array}{l}\text { zidovudine (AZT): } \\
2 \times 300 \mathrm{mg} \text { daily }\end{array}$ & + & $\begin{array}{l}\text { lamivudine } \\
(3 T C) \\
2 \times 150 \mathrm{mg} \\
\text { daily } \\
\end{array}$ & + & $\begin{array}{c}\text { nevirapine (NVP): } 2 \times 200 \mathrm{mg} \text { daily }{ }^{(a)} \\
\text { or } \\
\text { efavirenz }(E F V): 1 \times 600 \mathrm{mg} \text { at night }{ }^{(b)}\end{array}$ \\
\hline \multicolumn{5}{|c|}{ Second-line ARV regimens: } \\
\hline $\begin{array}{l}\text { zidovudine (AZT): } \\
2 \text { x 300mg daily }\end{array}$ & + & $\begin{array}{l}\text { lamivudine } \\
(3 T C) \\
2 \times 150 \mathrm{mg} \\
\text { daily }\end{array}$ & + & $\begin{array}{c}\text { Iopinavir/ritonavir (LPV/r): } \\
2 \times 400 / 100 \mathrm{mg} \text { daily } \\
\text { or } \\
\text { ritonavir-boosted atazanavir (ATV/r): } \\
\text { 300/100mg daily }\end{array}$ \\
\hline $\begin{array}{l}\text { tenofovir disoproxil } \\
\text { fumarate (TDF) : 300mg } \\
\text { daily }\end{array}$ & + & $\begin{array}{l}\text { lamivudine } \\
(3 T C) \\
2 \times 150 \mathrm{mg} \\
\text { daily }\end{array}$ & + & $\begin{array}{c}\text { lopinavir/ritonavir (LPV/r): } \\
2 \times 400 / 100 \mathrm{mg} \text { daily } \\
\text { or } \\
\text { ritonavir-boosted atazanavir (ATV/r): } \\
300 / 100 \mathrm{mg} \text { daily }\end{array}$ \\
\hline
\end{tabular}

Notes: Before 2011 stavudine (d4T) was used in the preferred treatment, but this drug has now been phased out due to toxicity concerns.
(a) Once daily for the first two weeks of treatment.
(b) Use efavirenz if patient cannot tolerate nevirapine.

\subsection{Patent status of medicines in prioritised first-line ARV regimen}

Here we explore the patent status of the priority ARV medicines. This provides key information about the quality of underlying patents. We use these data on patent quality as the basis for assessing whether these patents would be granted in Vietnam under alternative patent regimes and whether they would have term extensions. This then forms the basis for estimating the basic patent situation in our three different scenarios (section 5.4). As we do not have complete data on the patent status of efavirenz, we focus on the first-line regime of tenofovir (TDF), lamivudine (3TC) and nevirapine (NVP).

Tenofovir was originally synthesised in Czechoslovakia, with US patent 4,808,716 granted in February 1989. Some eight years later (July 1997) Californian pharmaceutical company Gilead filed for a US patent for tenofovir, after which it entered the global patenting route (PCT) in 1999. ${ }^{34}$ The US application was originally rejected on obviousness grounds - both compounds

\footnotetext{
${ }^{34}$ The Patent Cooperation Treaty (PCT) provides a single route for seeking patents in all signatory countries. The usual procedure is to file in the country of origin (or the USA), then proceed to a PCT application. The latter retains
} 
were known, as was the fact that conversion of a compound to its salt could enhance activity. Unless it could be shown that the salt possessed unexpected properties it was unpatentable. Naturally the applicant replied to the examiner to the effect that the salt did indeed possess unexpected properties - it had greater stability at higher humidity and temperature levels. On this basis a patent was granted in August 1999. But this demonstrates the very low inventiveness requirement for grant of a US patent. A similar application was rejected in Brazil in 2009, where pharmaceutical applications are referred to health specialists for assessment as to inventiveness (Shadlen 2011). Although Vietnam is listed in the designated states in the PCT application, we could find no record of the application being activated or granted in Vietnam.

A second tenofovir patent application- for the ester formulation - went through the PCT route based on an application at the USPTO. There is no evidence that this application was ever granted in the US, but it was granted by the European Patent Office (EPO) and in New Zealand. It was refused in Korea.

A third application - for combining tenofovir with emtricitabine (FTC) is complex to unravel. PCT/US2004/000832 was never granted in the US. ${ }^{35}$ It was originally granted by the EPO, but revoked in November 2010 after two companies opposed it. Gilead has appealed the revocation, and this appeal is still pending. Vietnam has granted a patent for the application that the EPO revoked. Drahos (Drahos 2008) cites Vietnam as one of several countries mentioning the EPO as a trusted office. This patent does not expire until 13 January 2024.

Lamivudine (3TC) has a complex patent history. The first application was in February 1989 (application 07/308101) with the inventors being Bernard Belleau from McGill University and Nghe Nguyen-Ba from Montreal-based pharmaceutical company IAF BioChem International, Inc. The patent claimed oxathiolane compounds (including optical isomers) with antiviral properties. Another 14 applications were filed with the USPTO over the following 16 years all related to this first application. Five of these were abandoned and nine were granted patents. In June 1991 Glaxo filed for a patent for crystalline oxathiolane derivates, then extended this globally using the PCT route (WO1992021676). There does not appear to be a US version of this patent. In 1997 Glaxo filed for another patent - for liquid compositions of lamivudine. This PCT application (WO1998042321) has been granted in Australia, at the EPO, in Israel, Korea and New Zealand. It has also been granted in Vietnam and does not expire until 20 March 2018. ${ }^{36}$

Nevirapine (NVP) also has one patent granted in Vietnam and another has been filed but has not yet been granted. The original nevirapine patent was filed on 13 July 1993 in the USA by Boehringer Ingelheim. ${ }^{37}$ FDA approval was obtained on 21 June 1996, meaning that Boehringer

the original application "priority date" - the date against which novelty and inventiveness is tested.

${ }^{35}$ Altogether Gilead filed ten US applications for combinations of TDF and FTC. Two are pending, four have been granted and four abandoned. Application 12/204,174, filed in September 2008 had a particularly troubled passage through examination. It was rejected five times as being obvious. The applicant made a number of changes to the claims and finally the examiner amended claim 47 to incorporate language about the degradation profile of the drug. A terminal disclaimer was also made with reference to an earlier application, meaning that this patent ceases in June 2026 rather than September 2028.

${ }^{36}$ Vietnamese patent VN1-0002847-000 granted in July 2002.

${ }^{37}$ Application 08/091418, granted as patent number 5,366,972 on 22 November 1994. In fact this application was a continuation of a number of patents filed in the period November 1989 to August 1991 and so might benefit from a priority date of as early as 17 November 1989. The priority date is the date at which the comparison with existing 
had just over 17 years of market exclusivity in the USA. ${ }^{38}$ This is some three years longer than the average period of 14 years of US market exclusivity for pharmaceuticals (Harris, Nicol and Gruen 2013: 82). The European patent grant (EP0429987) for this invention was given a term extension from 16 November 1990 to 23 June 2013. A patent for a hemihydrates formulation ${ }^{39}$ of nevirapine was filed in the USA in 1997 and two patents were granted: 6,172,059, expiring 11 August 2018 and 6,255,481 expiring 2 March 2020. The PCT version (WO1999009990) has led to granted patents in Australia, the EPO, Israel and New Zealand as well as Vietnam. Vietnamese patents VN1-0002478-000 granted in December 2001 and VN1-0002431-000 granted in November 2001 expire on 8 November 2018.

A third patent - for an extended release formulation of nevirapine - has been filed in Vietnam using the PCT route (WO2008154234). It is based on a 2009 US application (12/523226) claiming priority of 8 June 2007 from a provisional application. Application 12/523226 also had a difficult passage through the USPTO. It was rejected in November 2011 as unclear and obvious. The applicant then deleted 23 of the 24 claims, but it was again rejected as obvious. The applicant then withdrew the single remaining claim and substituted a marginally different single claim (see Box 1). As can be seen from the changes made to the single claim the major difference was a change from a patent for a composition to a patent for the use of the same composition to treat HIV. The specification of the hypromellose component was also changed, but only by deleting the trademark name. This case clearly demonstrates that the current patent standard of not obvious is based on semantics not substance. By 2009 the use of nevirapine for treatment of HIV was well known. Nothing about the extended release composition was inventive. So how could its use for a well-known purpose suddenly create sufficient inventiveness for grant of yet another nevirapine patent? Clearly, in the normal meaning of the term obvious, no patent should have been granted.

However such a patent was granted in the USA on 11 June 2013, and a term extension of 483 days was been granted because of delays in patent processing. Under claim 24 anyone can make the same formulation - they just cannot use it to treat HIV. A national phase entry of this application in Vietnam occurred in January 2009. It has not yet been granted. Patents have also been granted in Korea and the Ukraine. ${ }^{40}$

\footnotetext{
knowledge is made to test for novelty and inventiveness. Patent expiry would be 13 July 2013 unless there was a term extension. As the Food and Drug Administration (FDA) approved its use for adults on 21 June 1996 there is unlikely to be a term extension (http://en.wikipedia.org/wiki/Nevirapine accessed 26 Oct 2014). The patent was also granted by the EPO

${ }^{38}$ Calculated as the period from marketing approval on 21 June 1996 to patent expiry on 13 July 2013.

${ }^{39}$ This represents another salt of the same base molecule offering no difference in clinical effect.

${ }^{40}$ We have not had the time or resources to check whether these Korean and Ukrainian grants were for the composition or for its use in treating HIV.
} 
Box 1 Extended release nevirapine:

granted patent claim and differences from previously rejected obvious claim

Nevirapine, extended release formulation. US patent application 12/523226

Rejected claim 15 and accepted claim 24

Claim 1524

A method for treating HIV-1 infection which comprises once daily administration to a human infected by HIV-1 a Atablet pharmaceutical dosage from wherein each tablet comprises:

(a) $400 \mathrm{mg}$ of anhydrous nevirapine;

(b) $270 \mathrm{mg}$ of hypromellose 2208

(Anethocel'TM K4M Premium CR)

(c) $400 \mathrm{mg}$ of lactose monohydrate; and

(d) $10 \mathrm{mg}$ of Magnesium stearate

Wherein each tablet is compressed by a force of $10-25 \mathrm{kN}$.

Note: the editing shows the differences between the granted patent (in blue and black) and the rejected obvious claim (in black and red).

\subsection{Patent status of first-line ARVs under alternative patent policy scenarios}

With this background we can now turn to how the patent status of these medicines would pan out in Vietnam comparing use of the full TRIPS flexibilities, Vietnam's current policy settings, and the policy settings that would arise should the US IP proposals in the 2014 draft TPPA be accepted by Vietnam.

With regard to TDF, as there are no Vietnamese patents, with full TRIPS flexibility the only difference from the current scenario might be the use of compulsory licensing. Under the US TPPA proposals, a patent might well be granted for esters (as has happened at the EPO) as the inventive step required by TPPA Article E.1 is very low. Such a patent might also be eligible for a term extension, depending on the speed of marketing approval.

3TC has a Vietnamese patent for the liquid form, which might not be granted under full TRIPS flexibility due to the higher patenting standards possible. In practice this would make little difference to prices as the main form used is the tablet, which has no Vietnamese patent. Effectively there is no difference between the alternative patent regimes with respect to 3TC.

For NVP a patent for the hemihydrates form has been granted in Vietnam and does not expire until November 2018. Under full TRIPS flexibilities this patent could either have been refused, if a proper inventive step was in use, or a compulsory license could have been issued for this formulation. A patent for the extended release form has also been filed in Vietnam and, if granted, would not expire until 2029. This extended release patent is analysed in Box 1 above. Under any normal definition of inventiveness it would not be granted, so under the full TRIPS flexibilities scenario it would not exist. However, given the "any new use..." requirement of the 
TPPA Article E.1, it would have to be granted in Vietnam under the TPPA regime. It would not, however, qualify for a term extension. ${ }^{41}$

These alternative patent outcomes are summarised in Table 3.

Table 3 First-line ARVs: patent status under alternative policy scenarios

\begin{tabular}{|c|c|c|c|}
\hline Medicine & Trips full flexibilities & $\begin{array}{c}\text { Current Vietnam (VN) } \\
\text { regime }\end{array}$ & US TPPA regime \\
\hline TDF & $\begin{array}{l}\text { Pure TDF: No change from } \\
\text { current regime; } \\
\text { TDF+FTC: no VN patent }\end{array}$ & $\begin{array}{l}\text { No patents on TDF, but } \\
\text { patent on TDF+FTC }\end{array}$ & $\begin{array}{l}\text { Possible grant of patent } \\
\text { for esters as per EPO } \\
\text { Possible term extension } \\
\text { for ester patent }\end{array}$ \\
\hline 3TC & No patents & $\begin{array}{l}\text { Patent on liquid form } \\
\text { expires } 20 \text { March } 2018 .\end{array}$ & As for current regime \\
\hline NVP & No patents & $\begin{array}{l}\text { Patent on hemihydrate } \\
\text { form expires Nov } 2018 \\
\text { Possible patent on } \\
\text { extended release form (if } \\
\text { granted, expiry 2029) }\end{array}$ & $\begin{array}{l}\text { Patents on hemihydrate } \\
\text { form as per current } \\
\text { regime, with possible term } \\
\text { extension } \\
\text { Patent on extended } \\
\text { release form, no term } \\
\text { extension }\end{array}$ \\
\hline
\end{tabular}

\subsection{The pharmaceutical industry in Vietnam}

In 1989 Vietnam began a process of moving from a socialist economy to a mixed public-private economy. Until then medicines were heavily subsidised and each of the 63 provinces had a state-owned enterprise producing pharmaceuticals. Since then the market has been substantially opened, prices have increased considerably and there has been rationalisation in the domestic pharmaceutical industry. Most local manufacturing is assembly with 90 per cent of active ingredients imported. Distribution systems are complex and prices can vary considerably (Nguyen 2011: chapter 4). Although the government has made repeated efforts to bring clarity and a degree of control to prices, these have not yet succeeded (Nguyen et al. 2010). Locally produced ARVs cost less than imported products but are still five to seven times higher than the lowest international price (Nguyen 2011: chapter 3). The major overseas suppliers to the Vietnamese market are companies based in France, India, Korea, Switzerland and Germany.

Turning to the prices and suppliers of ARV products as at August 2014, there are 26 different $300 \mathrm{mg}$ TDF tablet products on the market in Vietnam. ${ }^{42}$ The price of a day's treatment for one person ranges from US\$0.52 to US\$2.73 (see Figure 1). The lowest priced product on the market is manufactured in Pakistan..$^{43}$ As the US patent was not filed until 1997, it will not expire in the USA until 2017 (or later if it has been granted an extension). But no patent has been granted in Vietnam or Brazil. It is therefore surprising that some suppliers price this medicine as high as

\footnotetext{
${ }^{41}$ Though a term extension would have been possible had the $2013 \mathrm{draft}$ text not been amended,

42 Drug Administration of Vietnam (http://www.dav.gov.vn/Default.aspx).

${ }^{43}$ The second lowest is Strides Arcolab Ltd.'s Virkil product, but in a $245 \mathrm{mg}$ tablet, so it may for use for a different treatment. It has been excluded from this analysis.
} 
US\$5.47 a day. It has been suggested that "many Vietnamese doctors [believe] that patentprotected branded drugs are more effective. As a result, foreign pharmaceutical companies dominate the market and maintain a revenue premium. ${ }^{14}$

As at August 2014 there are 40 different pure lamivudine (3TC) products on the market, all tablets. Most (31) are produced domestically. Surprisingly, given the treatment regime of 150 $\mathrm{mg}$ twice daily, most are provided as $100 \mathrm{mg}$ tablets - only four products are produced as $150 \mathrm{mg}$ products. ${ }^{45}$ Three of the $150 \mathrm{mg}$ tablets are domestically produced, with wholesale prices ranging from US\$0.15 to US\$0.62 per tablet. The imported product, sourced from Australia, is priced at US\$0.20 per tablet. The alternate first-line treatment regimen is AZT + 3TC + NPV and two other products combine AZT and 3TC; one combines all three.

There are only two NVP products on the market, one domestically produced and one imported. The daily treatment cost is US\$0.35 for the imported product and US\$0.47 for the domestically produced product. There is a single (domestically produced) zidovudine (AZT) product on the market and daily treatment costs US\$0.75.

Figure 1 TDF: daily treatment price (US\$s) by domestic and overseas suppliers

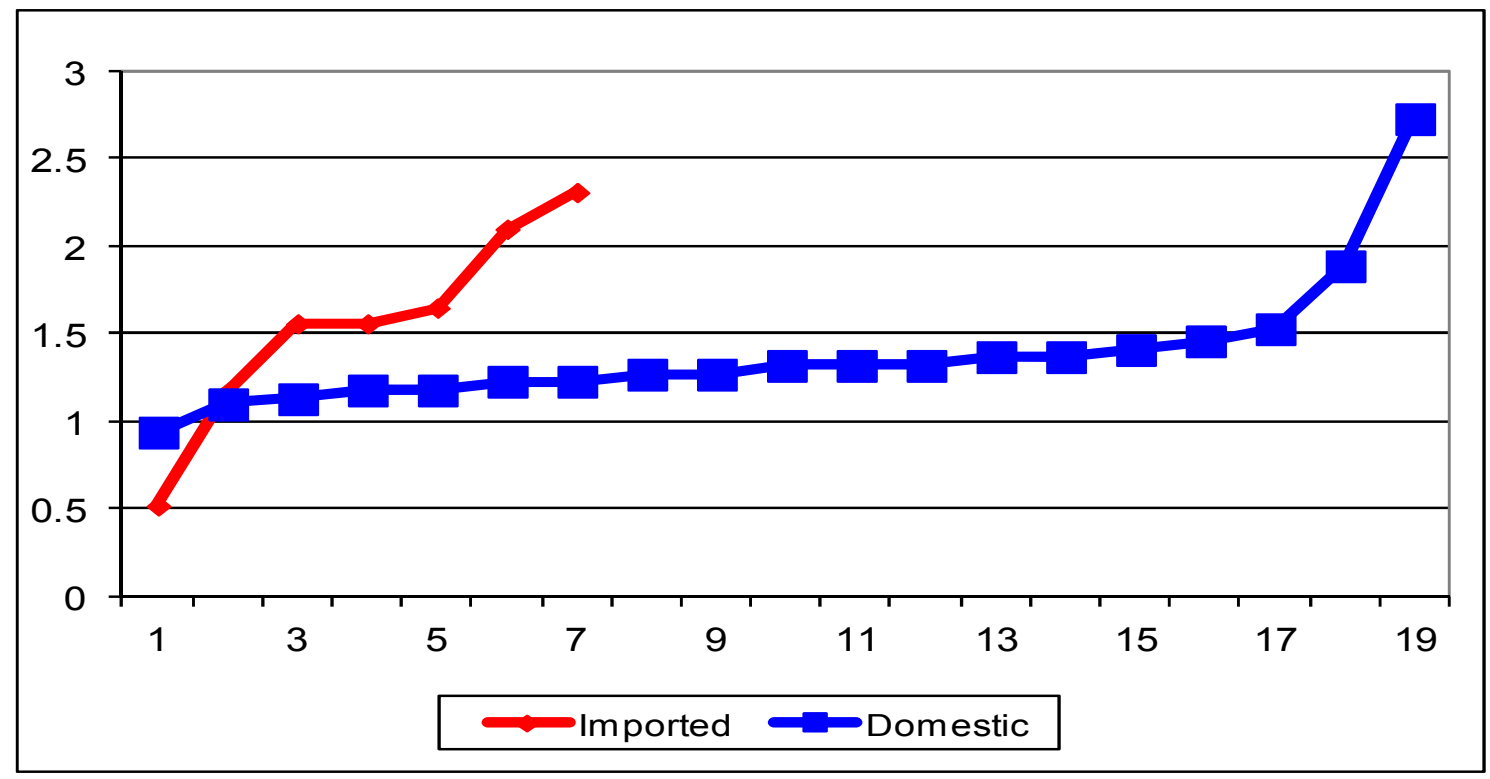

Summarising these data (Table 4) we find, using list prices, that the current treatment cost per person per day for the preferred first-line regimen ranges from US\$0.94 to US\$7.18 depending on the treatment regime and the specific products prescribed. The lowest daily treatment cost is for the alternate first-line regime of zidofudine (AZT) + 3TC + NVP. This product - SPM Jointstock Co.'s Efeladin - also has the advantage of being a fixed dose combination supplied as a single tablet, rather than requiring three tablets to be taken. The annual treatment cost per person per year (ppy) for Efeladin is US\$344. For the preferred first-line regime of TDF + 3TC + NVP the lowest priced option is US\$618 ppy.

\footnotetext{
${ }^{44}$ http://www.vietnam-briefing.com/news/vietnams-pharmaceutical-market-set-healthygrowth.html/\#sthash.NiHVWrJy.dpuf accessed 26 October 2014.

${ }^{45}$ For two products, the dose is unknown. One product is produced as a $300 \mathrm{mg}$ tablet. The remaining 33 are all $100 \mathrm{mg}$ tablets.
} 
Table 4 First-line ARVs: current medicine costs and treatment costs per person

\begin{tabular}{|c|c|c|}
\hline \multirow[t]{2}{*}{ Medicine } & \multicolumn{2}{|c|}{ Current Vietnam regime per person treated } \\
\hline & Daily cost (US\$) & Annual cost (US\$) \\
\hline TDF: $300 \mathrm{mg}$ daily & 1.05 to 5.47 & $383-1995$ \\
\hline 3TC: $150 \mathrm{mg} 2 \mathrm{x}$ daily & $0.30-1.24$ & $108-453$ \\
\hline NVP: $200 \mathrm{mg} 2 \mathrm{x}$ daily & $0.35-0.47$ & $127-172$ \\
\hline Total daily regimen cost $p p$ & $1.70-7.18$ & $618-2620$ \\
\hline AZT: $300 \mathrm{mg} 2 \mathrm{x}$ daily & 0.75 & 275 \\
\hline 3TC: $150 \mathrm{mg} 2 \mathrm{x}$ daily & $0.30-1.24$ & $108-453$ \\
\hline NVP: $200 \mathrm{mg} 2 \mathrm{x}$ daily & $0.35-0.47$ & $127-172$ \\
\hline AZT (300mg) + 3TC (150mg) & $1.13-1.35$ & $413-491$ \\
\hline AZT $(300 \mathrm{mg})+3 T C(150 \mathrm{mg})+$ NVP $(200 \mathrm{mg})$ & 0.94 & 344 \\
\hline Total daily regimen cost pp & $0.94-2.46$ & $344-2620$ \\
\hline
\end{tabular}

Source: calculated from data obtained from Drug Administration of Vietnam (http://www.dav.gov.vn/Default.aspx)

As much of the HIV treatment program is funded by overseas donors and the government, it is surprising that there are so many products on the market at substantial price premiums. But given the central funding, the government (or donors) can arrange to purchase the lowest price available product. In Table 5 we compare the lowest available prices in Vietnam to some international benchmarks - the originator prices for category 1 and category 2 countries and the best available world price. ${ }^{46}$ These data show that not only are Vietnamese prices markedly higher than the best available global prices, they are generally above category 1 and category 2 originator prices. The exception is Nevirapine (NVP). Although NVP sells at a mark-up of $488 \%$ on the best global price (Table 6), it is available in Vietnam at 50 per cent of the category 1 originator price or 28 per cent of the category 2 originator price.

Clearly, as Nguyen has pointed out, Vietnam needs to take further steps to ensure that the prices at which medicines are sold in Vietnam are reasonable. Although initial steps have been taken to introduce measures to ensure reasonable prices, these have yet to gain traction. Such policy changes might be limited by the TPPA, a matter discussed further in section 6 below.

\footnotetext{
${ }^{46}$ Depending on the supplier, Vietnam is classed either as a category 1 country or as a category 2 country. Bristol Myers Squibb and Gilead class Vietnam as category 1, while Abbvie/Abbott, Boehringer-Ingelheim and Merck all class Vietnam as category 2 (Médecins Sans Frontières (MSF) 2013: 73-77).
} 
Table 5 First-line ARVs: annual treatment costs (US\$s), Vietnam and globally

\begin{tabular}{|l|c|c|c|c|}
\hline Medicine & $\begin{array}{c}\text { Lowest cost } \\
\text { in Vietnam }\end{array}$ & \multicolumn{2}{|c|}{ Originator price } & $\begin{array}{c}\text { Best global } \\
\text { price }\end{array}$ \\
\hline & & $\begin{array}{c}\text { Country 1 } \\
\text { category }\end{array}$ & $\begin{array}{c}\text { Country 2 } \\
\text { category }\end{array}$ & \\
\hline TDF: $300 \mathrm{mg}$ daily & 383 & 207 & 365 & 26 \\
\hline 3TC: $150 \mathrm{mg} 2$ x daily & 108 & 75 & -- & 24 \\
\hline NVP: $200 \mathrm{mg} 2$ x daily & 127 & 219 & 438 & 26 \\
\hline Total daily regimen cost pp & 618 & 501 & & \\
\hline & & & & \\
\hline AZT: 300mg 2 x daily & 275 & --- & -- & 24 \\
\hline 3TC: $150 \mathrm{mg} 2 \times$ daily & 108 & 75 & -- & 26 \\
\hline NVP: $200 \mathrm{mg} 2 \times$ daily & 127 & 219 & 438 & 79 \\
\hline AZT (300mg) + 3TC (150mg) & 413 & 169 & --- & 100 \\
\hline AZT (300mg) + 3TC (150mg) + NVP (200mg) & 344 & -- & -- & \\
\hline Total daily regimen cost pp & $344-510$ & & & \\
\hline
\end{tabular}

Source: $\quad$ Calculated from data in MSF, 2014: Annex 1 and data in Table 4 above.

Table 6 Benchmarking Vietnam prices: percentage of given comparator price

\begin{tabular}{|l|c|c|c|}
\hline Medicine & $\begin{array}{c}\text { Best global } \\
\text { price }\end{array}$ & $\begin{array}{c}\text { Originator price } \\
\text { Category 1 } \\
\text { country }\end{array}$ & $\begin{array}{c}\text { Originator price } \\
\text { Category 2 } \\
\text { country }\end{array}$ \\
\hline TDF: $300 \mathrm{mg}$ daily & $1473 \%$ & $185 \%$ & $105 \%$ \\
\hline 3TC: $150 \mathrm{mg} 2 \times$ daily & $450 \%$ & $144 \%$ & \\
\hline NVP: $200 \mathrm{mg} 2 \times$ daily & $488 \%$ & $58 \%$ & $29 \%$ \\
\hline Total daily regimen cost pp & $813 \%$ & & \\
\hline & & & \\
\hline AZT: $300 \mathrm{mg} 2 \times$ daily & $399 \%$ & & \\
\hline AZT (300mg) + 3TC (150mg) & $523 \%$ & $144 \%$ & \\
\hline AZT (300mg) + 3TC (150mg) + NVP (200mg) & $344 \%$ & $244 \%$ & \\
\hline
\end{tabular}

Source: $\quad$ Based on Table 5. 


\section{$6 \quad$ Results and implications}

\subsection{Estimating ARV treatment under different patent policies}

Presuming that Vietnam is able to take effective steps to curtain excessive profit-taking in the pharmaceutical market, then the data in Table 5 provide a basis for comparing the impact of alternative patent policy scenarios on the cost of supplying ARV drugs to the HIV population. We start by looking at the best available current Vietnamese price for any first-line regimen as the price for scenario 1. From Table 5, this price is US\$334 ppy, based on the combination product AZT + 3TC + NVP, supplied under the brand name Efeladin by the Vietnamese SPM Joint-Stock Company. This is consistent with a 2012 Viet Nam Administration of HIV/AIDS Control (VAAC)/ US Centers for Disease Control and Prevention (CDC)/World Health Organization (WHO) study reporting first-line ART provision at US\$365 per patient per year for the first year and US\$312 for subsequent years. ${ }^{47}$ However, we also know there is a budget of US\$25.1m for care and treatment and that this is providing ARV treatment for almost 83,000 people living with HIV. This implies an average outlay of US\$304 per person for all care and treatment, including the cost of medicines. Clearly the Vietnamese government is obtaining ARV supplies at well under \$334 per person. From Duong and colleagues (2014) we know that the ARV share of treatment costs is around $42 \%{ }^{48}$ This gives an estimate of the medicines cost of treatment as US\$127 ppy and the non-medicines cost of treatment as US\$176 ppy.

This estimated outlay on ARVs of US\$127 is used for scenario 1 - the current Vietnamese patent policy setting. Clearly, on the basis of these estimates, the government is actually able to obtain ARVs at prices well below the list price. Even this cost is, however, greater than the best global prices available. Using the best global prices for the preferred first-line regimen of TDF + 3TC + NVP, the price per patient per year is US\$76. If Vietnam is able to institute effective policies over medicine prices, then the patent situation under full TRIPS flexibilities should allow the government to obtain medicine supplies at these world-best prices. We use this price setting for scenario 2. This gives a per person treatment cost of US\$252 (\$76 plus \$176) compared to the current average cost of US\$304.

Under scenario 3, the patent policies being asked by the USA in the context of the TPPA negotiations, we consider that further patents, and patent term extensions, could restrict access to ARV medicines compared to the current situation (see Table 3 above). In this situation prices are likely to be originator prices. Current MSF data shows these to be US\$501 for originator products in category 1 countries for the preferred regimen of DF + 3TC + NVP (see Table 5). Depending on the supplier, Vietnam is sometimes considered as a category 2 country, in which case prices would be higher. Against this, however, is the clear ability to obtain medicines at below the listed prices. We therefore take US\$501 as the medicine cost for scenario 3.

The results of this analysis are presented in Table 7. As anticipated, if Vietnam were able to use full TRIPS flexibilities, and obtain ARVs at world-best prices, then the proportion of the

\footnotetext{
${ }^{47}$ VAAC, CDC, WHO. VAAC Costing Study. 2012.

${ }^{48}$ Table 1 in Duong et al., 2014, shows that the average cost of first-line treatment ARVs is $37 \%$ in the first year and $47 \%$ in subsequent years. Here we use the average of $42 \%$. We also know that only $3 \%$ of people treated are on second-line ARVs. Because this is such a low proportion, and our estimates are quite rough, we have chosen to ignore second-line treatments in our calculations.
} 
population who meet the treatment criteria and receive ARV treatment with the available budget would increase to $82 \%$. Equally however, should Vietnam implement the further reductions in patent quality and extend originator monopolies as proposed in the TPPA, then prices could rise substantially. We have estimated a price increase to $\$ 501$, in which case, given the budget constraint, treatment would fall to $30 \%$ of the eligible population. This is less than half of the population currently being treated - over 45,000 people would no longer receive treatment.

Table $7 \quad$ Alternative treatment capabilities depending on patent policy setting

\begin{tabular}{|l|l|c|c|c|c|c|}
\hline & $\begin{array}{l}\text { Available } \\
\text { budget }\end{array}$ & $\begin{array}{l}\text { Number } \\
\text { treated }\end{array}$ & $\begin{array}{c}\text { Non-drug } \\
\text { treatment } \\
\text { costs ppy }\end{array}$ & $\begin{array}{c}\text { Medicine } \\
\text { cost ppy }\end{array}$ & \% treated & $\begin{array}{c}\text { PLHIV } \\
\text { eligible for } \\
\text { ARVs }\end{array}$ \\
\hline Scenario 1 & $25,100,000$ & 82,687 & 176 & 127 & 68 & 121,599 \\
\hline Scenario 2 & $25,100,000$ & 99.579 & 176 & 76 & 82 & 121,599 \\
\hline Scenario 3 & $25,100,000$ & 37,072 & 176 & 501 & 30 & 121,599 \\
\hline Scenario 3b & $25,100,000$ & 58,230 & 176 & 255 & 48 & 121,599 \\
\hline Scenario 3c & $25,100,000$ & 26,673 & 176 & 765 & 22 & 121,599 \\
\hline
\end{tabular}

Notes: scenario $3 b$ is based on drug prices increasing by a factor of two; in scenario $3 c$, drug prices increase by a factor of six.

Of course, prices might not rise quite so severely under scenario 3. In Jordan, Abbott and colleagues estimated an average price increase of $17 \%$, which would bring the price only to US\$149. If this eventuated, while the proportion treated would fall, it would only be by 5 percentage points, some 5,500 fewer people treated. But the Jordan studies also showed that drugs in Jordan could be between two and six times higher than in Egypt where there are no TRIPS+ policies. For our scenario 3, that would mean drug costs of US\$255 to US\$765. If drug costs were four times higher they would be $\$$ US510 - very close to our initial estimate for scenario 3.

\subsection{Pharmaceutical price regulation: risks arising from the TPPA}

While the focus of this paper is on the patent and data protection provisions proposed for the TPPA and their effects on medicine prices, there are other provisions in the TPPA that could prevent effective pharmaceutical price regulation in the future. An annex to the transparency chapter (often referred to as the 'Healthcare Transparency Annex') proposed by the USA in 2011 sought to place restrictions on pricing, and in particular would have ruled out therapeutic reference pricing, an important strategy for ensuring value for money (Lopert and Gleeson 2013). Recent reports suggest that the USA has retreated from its initial position in the face of opposition from other TPPA countries and from non-government organisations (NGOs), ${ }^{49}$ and that the current version of the annex is more similar to Annex 2-C of AUSFTA, which contained no pricing provisions. However, it seems unlikely that the USA will readily give up one of its key offensive interests and the healthcare transparency annex appears to remain an outstanding

${ }^{49}$ Inside U.S. Trade (2014) U.S. Poised to Scale Back TPP Proposal on Drug Reimbursement Rules. 17 January, 2014. 
area of disagreement in the final stages of the negotiations.

Also of concern is the proposed investor-state dispute settlement (ISDS) mechanism in the investment chapter of the TPPA. ISDS provides a route for investors to directly sue governments for monetary compensation when policies are introduced that affect the value of their investments. Anecdotal evidence suggests that ISDS will not apply to the obligations of the IP chapter, but that intellectual property is likely to be included in the definition of investment. ${ }^{50}$ Moreover, ISDS may apply to the obligations of the healthcare transparency annex (unless it is specifically carved out) or to new developments in pharmaceutical policy more broadly. Since defending an ISDS case generally costs millions of dollars (and the awards can amount to hundreds of millions) (Gleeson, Tienhaara and Faunce 2012), the availability of this mechanism to US pharmaceutical companies may deter developing country governments from putting effective price control mechanisms in place.

\section{Conclusion}

The findings of this analysis substantiate concerns raised by academics and NGOs that the TPPA will have a deleterious effect on access to medicines, particularly in the lower income countries participating in the negotiations. Although the 2014 version of the draft text is less damaging than previous versions in many ways, we have shown that it will still significantly impede access to life-saving medicines.

Currently Vietnam is able to provide anti-retroviral therapy to $68 \%$ of those people living with HIV who meet the clinical criteria for such treatment. Under provisions still being considered by the TPPA countries in 2014, we estimate that only $30 \%$ of Vietnam's eligible HIV patients ${ }^{51}$ would have access to ARVs. In contrast, if Vietnam were to utilise the full flexibilities available under the TRIPS Agreement and the Doha Declaration, an estimated $82 \%$ of the population eligible for ARV treatment would be covered. For Vietnam, signing the TPPA will put the use of these TRIPS flexibilities further out of reach. Furthermore, provisions in other TPPA chapters may also prevent Vietnam from introducing effective pricing policies and pharmaceutical regulations that help to drive down prices and ensure value for money.

Overall there are substantial reasons why governments should be concerned by some of the TPPA proposals - they will make achieving the requirements of TRIPS Article 7 (that patent policy should be balanced between the interests of producers and users of new technology) impossible. They will also create a road block to achieving two of the Millennium Development Goals. Goal 6 is combat HIV/AIDS, malaria and other diseases, with Target 6B specifically aiming for universal access to treatment for HIV/AIDS for all those who need it by 2010. Goal $8 \mathrm{E}$ is to provide access to affordable essential medicines in developing countries.

\footnotetext{
${ }^{50}$ Such concerns are based, in part, on Eli Lilly's legal suit against the Canadian government because Canadian courts invalidated two of their patents.

${ }^{51}$ i.e. the proportion of those who meet the clinical criteria for ARV treatment.
} 


\section{References}

Abbott, R.B., et al. 2012. "The price of medicines in Jordan: the cost of trade-based intellectual property." Journal of Generic Medicines 9(2):75-85.

Akaleephana, C., et al. 2009. "Extension of market exclusivity and its impact on the accessibility to essential medicines, and drug expense in Thailand: Analysis of the effect of TRIPs-Plus proposal." Health Policy 91:174-182.

Amin, T. and A.S. Kesselheim. 2012. "Secondary patenting of branded pharmaceuticals: a case study of how patents on two HIV drugs could be extended for decades." Health Affairs 31(10):2286-2294.

Baker, B.K. 2008. "Ending Drug Registration Apartheid: Taming Data Exclusivity and Patent/Registration Linkage." American Journal of Law \& Medicine 34:303-344.

-. 2013. "US's Proposed TPP Transition Period for Middle-Income Parties is Fools Gold."

Berndt, E.R. and M.L. Aitken. 2011. "Brand Loyalty, Generic Entry and Price Competition in Pharmaceuticals in the Quarter Century after the 1984 Waxman-Hatch Legislation." International Journal of the Economics of Business 18(2):177-201.

Bhardwaj, K. and C. Oh. 2014. "The Trans-Pacific Partnership Agreement: Implications for Access to Medicines and Public Health. UNITAID, WHO." UNITAID.

Bouchard, R.A., et al. 2010. "Empirical analysis of drug approval-drug patenting linkage for high value pharmaceuticals." Northwestern Journal of technology and Intellectual Property 8(2):174-227.

Bouchard, R.A., et al. 2009. "The Pas de Deux of Pharmaceutical Regulation and Innovation: Who's Leading Whom?" Berkeley Technology Law Journal 24:1461-1522.

Branstetter, L.G., et al. 2011. "Regulation and Welfare: Evidence from Paragraph IV Generic Entry in the Pharmaceutical Industry." National Bureau of Economic Research, Working Paper 17188.

Burdon, M. and K. Sloper. 2003. "The Art of Using Secondary Patents to Improve Protection." Journal of Medical Marketing 3(3):226-238.

Chan, M. 2014. "Health has an obligatory place in any post-2015 agenda. ." Address to the Sixty-seventh World Health Assembly, Geneva, 19 May 2014

Chaudhuri, S., et al. 2006. "Estimating the Effects of Global Patent Protection in Pharmaceuticals: A Case Study of Quinolones in India." The American Economic Review 96(5):1477-1514.

Christie, A.F., et al. 2013. "Patents Associated with High-Cost Drugs in Australia." PLOS One 8(4):1-7.

Cohen, J.C. and K.M. Lybecker. 2005. "AIDS Policy and Pharmaceutical Patents: Brazil's Strategy to Safeguard Public Health." The World Economy 28(2):211-230.

Colombo, G.L., et al. 2013. "Off-Patent Generic Medicines vs. Off-Patent Brand Medicines for Six Reference Drugs: A Retrospective Claims Data Study from Five Local Healthcare Units in the Lombardy Region of Italy." PLOS One 8(12):1-9.

Deere, C. 2009. The Implementation game: The TRIPS Agreement and the Global Politics of Intellectual Property Reform in Developing Countries. Oxford: Oxford University Press.

Drahos, P. 2007. "Four Lessons for Developing Countries from the Trade Negotiations Over Access to Medicines." Liverpool Law Review 28(1):11-39.

-. 2008. "“Trust Me": Patent Offices in Developing Countries." American Journal of Law \& Medicine 34. 
Dunne, S., et al. 2013. "A review of the differences and similarities between generic drugs and their originator counterparts, including economic benefits associated with usage of generic medicines, using Ireland as a case study, ." 14(1):19.

Duong, A.T., et al. 2014. "Costing analysis of national HIV treatment and care program in Vietnam." Journal of Acquired Immune Deficiency Syndrome 65(1):e1-e7.

Dutfield, G. 2003. Intellectual Property Rights and the Life Science Industries: A 20th Century History. Burlington: Ashgate.

Dutta. 2011. "From Free Entry to Patent Protection: Welfare Implications for the Indian Pharmaceutical Industry." The Review of Economics and Statistics 93(1):160-178.

Dylst, P. and S. Simoens. 2011. "Does the Market Share of Generic Medicines Influence the Price Level? A European Analysis." Research Centre for Pharmaceutical Care \& Pharmaco-economics, K.U.Leuven, Leuven, Belgium.

European Commission. 2009. "Final Report: Competition Inquiry into the Pharmaceutical Sector." Brussels: European Commission.

Flynn, S., et al. 2012. "The U.S. proposal for an intellectual property chapter in the Trans-Pacific Partnership Agreement." American University International Law Review 28(1):105-202.

Flynn, S., et al. 2009. "An Economic Justification for Open Access to Essential Medicine Patents in Developing Countries." Journal of Law, Medecine \& Ethics 37:184-208.

Frank, R.G. and D.S. Salkever. 1997. "Generic Entry and the Pricing of Pharmaceuticals." Journal of Economics and Management Strategy 6(1):75-90.

Furrow, M.E. 2008. "Pharmaceutical Patent Life-Cycle Management after KSR v. Teleflex." Food and Drug Law Journal 63(1):275-320.

Gleeson, D.H., et al. 2012. "Challenges to Australia's national health policy from trade and investment agreements." Medical Journal of Australia 196:1-3.

Godoy, A.S. and A. Cerón. 2011. "Changing Drug Markets Under New Intellectual Property Regimes: The View From Central America." American Journal of Public Health 101(7):1186-1191.

Grootendorst, P. and A. Hollis. 2011a. "The 2011 Canada-European Union Comprehensive Economic and Trade Agreement: An Economic Impact Assessment of Proposed Pharmaceutical Intellectual Property Provisions." Journal of Generic Medicines 8(2):81-103.

-. 2011b. "The Canada-European Union Comprehensive Economic \& Trade Agreement: An Economic Impact Assessment of Proposed Pharmaceutical Intellectual Property Provisions."

Harris, T., et al. 2013. "Pharmaceutical Patents Review Report." Canberra, available at http://www.ipaustralia.gov.au/pdfs/2013-05-27_PPR_Final_Report.pdf.

Hollis, A. 2003. "The Anti-Competitive Effects of Brand-Controlled 'Pseudo-Generics' in the Canadian Pharmaceutical Market." Canadian Public Policy 29(1):21-32.

Huckfeldt, P.J. and C.R. Knittel. 2011. "Pharmaceutical Use Following Generic Entry: Paying Less and Buying Less ". NBER Working Paper No. 17046

IFARMA and Fundacion Mision Salud. 2009a. "Impact of the EU-Andean Trade Agreement on Access to Medicines in Colombia."

-. 2009b. "Impact of the EU-Andean Trade Agreement on Access to Medicines in Peru." 
Jones, J.C.H., et al. 2001. "Patents, brand-generic competition and the pricing of ethical drugs in Canada: some empirical evidence from British Columbia, 1981- 1994." Applied Economics 33:947-956.

Kamien, M.I. and I. Zang. 1999. "Virtual Patent Extension by Cannibalization." Southern economic journal 66(1):117-131.

Kapczynski, A., et al. 2012. "Polymorphs and Prodrugs and Salts (Oh My!): An Empirical Analysis of "Secondary" Pharmaceutical Patents." PLOS One 7(12):e49470.

Kessomboon, N., et al. 2010. "Impact on access to medicines from TRIPS-Plus: A case study of Thai-US FTA." Southeast Asian Journal of Tropical Medicine and Public Health 41(3):667-677.

Kiliç, B. and P. Maybarduk. 2011. "Comparative Analysis of the United States' TPFTA Intellectual Property Proposal and Vietnamese Law." Public Citizen, June 2011 (updated December 2011) Available at: www.citizen.org/access.

Kong, Y. and J.R. Seldon. 2004. "Pseudo-Generic Products and Barriers to Entry in Pharmaceutical Markets." Review of Industrial Organization 25:71-86.

Kvesic, D.Z. 2008. "Product Lifecycle Management: Marketing Strategies for the Pharmaceutical Industry." Journal of Medical Marketing 8:293-301.

Lexchin, J. 2011. "Canada's Patented Medicine Notice of Compliance regulations: balancing the scales or tipping them?" BMC Health Services research 11:64.

Lexchin, J. and M.-A. Gagnon. 2014. "CETA and pharmaceuticals: impact of the trade agreement between Europe and Canada on the costs of prescription drugs, ." Globalization and Health 10:30-.

Lopert, R. and D. Gleeson. 2013. "The high price of 'free" trade: U.S. trade agreements and access to medicines." Global Health and the Law:199-223.

Maskus, K.E. 2001. "Parallel imports in pharmaceuticals: implications for competition and prices in developing countries."

Médecines Sans Frontières. 2013. "As Trans-Pacific trade talks accelerate, vital lifeline of affordable medicines under threat."

Médecins Sans Frontières (MSF). 2013. "Untangling the web of antiretroviral price reductions, 16th edition."

-. 2014. "Untangling the web of antiretroviral price reductions, 17th edition."

Moir, H.V.J. 2013. "Fabricating invention: the patent malfunction of Australian patent law." Agenda 20(2):21-38.

Nguyen, A.T. 2011. "Medicine prices and priccing policies in Vietnam." PhD, Faculty of medicine, University of New South Wales.

Nguyen, A.T., et al. 2010. "Medicine pricing policies: Lessons from Vietnam." Southern Med Review 3(2).

Ouellette, L.L. 2010. "How Many Patents Does It Take To Make a Drug? Follow-On Pharmaceutical Patents and University Licensing." Michigan Telecommunications and Technology Law Review 17:299336.

Oxfam International. 2007. "All costs, no benefits: How TRIPS-plus intellectual property rules in the USJordan FTA affect access to medicines." 
Rosenberg, S.T. 2014. "Asserting The Primacy Of Health Over Patent Rights: A Comparative Study Of The Processes That Led To The Use Of Compulsory Licensing In Thailand And Brazil." Developing World Bioethics.

Schaffer, E.R. and J.E. Brenner. 2009. "A Trade Agreement's Impact on Access to Generic Drugs. ." Health Affairs 28(5):w957-w968.

Scherer, F.M. and S. Weisburst. 1995. "Economic effects of strengthening pharmaceutical patent protection in Italy." International Review of Industrial Property and Copyright Law 26(6):1009-1024.

Shadlen, K.C. 2011. "The rise and fall of "prior consent" in Brazil." The WIPO Journal 3(1):102-112.

Shaffer, E.R. and J.E. Brenner. 2009. "A trade agreement's impact on access to generic drugs." Health Affairs 28(5):w957-w968.

Stargardt, T. 2011. "Modelling pharmaceutical price changes in Germany: a function of competition and regulation. ." Applied Economics 43:4515-4526.

Veras. 2014. "Making Tenofovir accessible in the Brazilian public health system: patent conflicts and generic production." Developing World Bioethics:1471-8731 (print) 1471-8847 (inline).

Waning, B., et al. 2010. "A lifeline to treatment: the role of Indian generic manufacturers in supplying antiretroviral medicines to developing countries." Journal of the International AIDS Society 13(35).

Weber, A. and L. Mills. 2010. "A one-time-only combination: emergency medicine exports under Canada's access to medicines regime. ." Health and Human Rights in Practice 12(1):109-122. 